\title{
Just Interested or Getting Involved? An Analysis of Superannuation Attitudes and Actions*
}

\author{
HAZEL BATEMAN \\ School of Risk \& Actuarial \\ Studies, University of New South \\ Wales, Sydney, Australia \\ BEN R. NEWELL \\ School of Psychology, \\ University of New South Wales, \\ Sydney, Australia
}

\author{
JEANETTE DEETLEFS \\ School of Marketing, University \\ of New South Wales, Sydney, \\ Australia \\ ANDREAS ORTMANN \\ School of Economics, University \\ of New South Wales, Sydney, \\ Australia
}

\section{LORETTI I. DOBRESCU CEPAR and School of} Economics, University of New South Wales, Sydney, Australia

\author{
SUSAN THORP \\ Finance Discipline Group, \\ University of Technology, \\ Sydney, Australia
}

\begin{abstract}
Low levels of non-default decision-making among superannuation members in Australia are assumed to be evidence of a lack of interest and capability. Using member records and survey data from a large Australian superannuation fund, we test the relationship between attitudes towards retirement savings and observable levels of non-default activities (such as making voluntary contributions, choosing or changing investment options and changing insurance cover). Additional retirement savings contributions by permanent staff are more likely if the staff member is very likely to recommend their superannuation fund. Individuals who rate their own personal interest in superannuation affairs as very high are more likely to be active online. This, however, does not extend to choosing a nondefault investment or purchasing additional insurance, where we find no differences between the highly interested and the disengaged. These findings, together with several other differences related to demographics and employment conditions, show that nondefault activity is not a reliable proxy for member engagement.
\end{abstract}

\footnotetext{
*The authors are especially grateful to Jacs Davis and other staff at UniSuper, and to Megan Gu and Danny Yeung for excellent research assistance. Research support from the Australian Research Council LP110100489, the Australian Research Council Future Fellowship FT110100151 (Newell), the Centre of Excellence in Population Ageing Research (CEPAR), under project CE110001029 (Dobrescu), and the Australian School of Business (Deetlefs) is gratefully acknowledged. The Chair of Finance and Superannuation, UTS, (Thorp) receives support from the Sydney Financial Forum (through Colonial First State Global Asset Management), the NSW Government, the Association of Superannuation Funds of Australia (ASFA), the Industry Superannuation Network (ISN) and the Paul Woolley Centre for the Study of Capital Market Dysfunctionality, UTS.
}

JEL classifications: G02, G28, D14

Correspondence: Hazel Bateman, School of Risk \& Actuarial Studies, University of New South Wales, Sydney, NSW 2052, Australia. Email: h.bateman@unsw.edu.au 
Australians have contributions made to their super funds whether they like it or not. Members should not have to be interested, financially literate, or investment experts to get the most out of their super funds. If members want to engage and make choices, then the system ought to encourage and facilitate them doing so. If members are not interested, then the system should still work to provide optimal outcomes for them. The super system should work for its members, not vice versa. This is the basis of the Panel's new 'choice architecture.' Super System Review (2010) Final Report Part One: Overview and Recommendations, p.1.

\section{Introduction}

Libertarian paternalism (Thaler \& Sunstein, 2003) has become the modus operandi of retirement savings systems around the world (Antolin et al., 2012). While standard economic theory predicts that individuals will voluntarily prepare for retirement, governments commonly compel or 'nudge' workers towards at least a minimum level of retirement savings, often at considerable public expense. Justifications for intervention include planning failures related to bounded rationality, bounded self-control, tax distortions, incomplete insurance markets, moral hazard caused by public income support or behavioural biases (Diamond, 1977, 2011; Bateman et al., 2001; Mitchell \& Utkus, 2006).

The idea that passive or irrational agents need to be 'nudged' into beneficial contribution rates, investment options and insurance plans, has wide acceptance. Indeed, many of the recommendations of the recent review into the Australian superannuation system are founded on the assumption that many (if not most) members have neither the capability nor the interest necessary for the 'system to work properly' (Super System Review, 2010, p. 9). The Review Committee argued that past reliance on disclosure and market conduct controls are insufficient for economic efficiency if fund members are not the rational and well-informed decision-makers they were assumed to be.

The evidential support used by the Review panel to confirm this lack of interest and capability was twofold: First, after the 'Choice of Fund' legislation was passed, allowing members to choose a superannuation fund different from the default fund used by their employer, fewer members switched fund than before the legislation was passed. Second, there was 'anecdotal' evidence that only 20 per cent of the 80 per cent of members in default investment options (in 2009) were there because of an active preference for that option (Super System Review, 2010, p.9). The Review Committee admitted that defining and measuring engagement and interest in superannuation was difficult. However, low levels of measured activity, accompanied by a limited or even anecdotal interpretation that lays the blame on disengagement, were sufficient to motivate a move to 'libertarian paternalistic' policy.

In this study, we use two rich datasets from a large Australian superannuation fund to test the connection between attitudes towards retirement savings and observable non-default choices. We ask whether interest and involvement in superannuation (as proxies for engagement) consistently show up as non-default choices, and if they do, what choices or activities are strong indicators. We compare individuals' subjective assessments of their own personal involvement with superannuation, and their specific superannuation fund, with their activity. By comparing the actions of interested individuals with the actions of uninterested individuals we can evaluate which activities are the best indicators of personal interest or engagement.

There are several previous studies in the Australian context that have examined choice of superannuation fund (Fry et al., 2007), the choice between defined benefit (DB) and defined contribution (DC) plans (Brown et al., 2004; Gerrans \& Clark-Murphy, 2004), and the investment choice (Gerrans et al., 2010). Non-default behaviour is evident across all three domains, but the link with self-reported interest/involvement/engagement has not been addressed so far.

The divide between 'rational' and 'real-world' retirement saving is clear in the behaviour of retirement savers when left to their own devices. Before the introduction of the mandatory Superannuation Guarantee few Australians participated in superannuation on a voluntary basis, despite generous tax incentives (Bateman \& Piggott, 1997). Moreover, in the United States, where workers were required to take specific action to participate, many failed to voluntarily enrol in $401 \mathrm{k}$ plans, despite the benefits of tax deferral and employer matching (Benartzi, 2012). Even with automatic enrolment, $401 \mathrm{k}$ plan members tend to stick with their initial contribution and asset allocation settings (Madrian \& Shea, 2001). 
The introduction of defaults in policy and plan design has become a popular response to closing the gap between rational and actual retirement savings behaviour. Recent examples include automatic enrolment (with opt out) in New Zealand, the United Kingdom and Italy (Antolin et al., 2012), automatic enrolment and escalation in $401 \mathrm{k}$ plan design (Benartzi, 2012), and the default investment strategy in Australia's MySuper product. ${ }^{1}$

A recent panel study of the Danish population's savings decisions demonstrated that incentives, such as changes to savings subsidies that required individual action, had small impacts on total wealth. Passive changes, however, such as automatic changes in contribution rates, had large effects on the overall net savings and led to higher accumulations at retirement (Chetty et al., 2012). The authors conclude that policies that automatically impact the 85 per cent of the population who were classified as 'passive' savers have the largest results. The 15 per cent 'active' group who adjusted their savings in response to subsidies tended to offset one form of saving with another. 'Active' savers had higher wealth/income ratios, tended to be middle-aged (most likely in their 50s), better educated and especially had some economics or finance training. Similarly, in the US context, Benartzi and Thaler (2013) report that auto-enrolment and auto-escalation significantly increase $401 \mathrm{k} \mathrm{cov-}$ erage and savings rates.

It is clear, therefore, that defaults can have a significant impact on behaviour. What is less clear is how the default options actually influence decisions. There is a wide range of possibilities, ranging from being used by the uninterested, disengaged or incapable people, as a simplification heuristic, as a form of advice, or as creating a momentum for future decisions (Beshears et al., 2009; de Haan \& Linde, 2012; Carlin et al., 2013). However, 'involvement' (i.e. personal interest) has been found to decrease the likeli-

\footnotetext{
${ }^{1}$ MySuper, one of the key recommendations of the Super System review, is a default superannuation product with a single diversified or lifecycle investment strategy and default insurance cover. From 1 January 2014 a MySuper product is the 'default option' for those who have not chosen a superannuation fund (Superannuation Legislation Amendment-MySuper Core Provisions-Act 2012; Australian Government, 2010).
}

hood of choosing a default investment option (Hedesström et al., 2007).

Our findings show that personal interest in superannuation and the number of non-default choices are not simple proxies for each other. Furthermore, age, income, gender and employment status have independent effects on active choices over and above personal attitudes to superannuation. As such, public policy based on the presumed equivalence of personal interest (or engagement) and non-default choices could be misguided.

We proceed as follows: In Section 2 we set up the policy background for our sample, including the special features of UniSuper - our exemplar superannuation fund. Section 3 gives a detailed description of the datasets and Section 4 describes the results relating to contributions and accumulation patterns. Section 5 concludes with a discussion of policy implications and areas for future research.

\section{Policy and Institutional Background}

Australia's retirement income system is a three-pillar arrangement, comprising: (i) a means-tested Age Pension financed from general tax revenue; (ii) a mandatory employer-financed defined contribution system, known as the Superannuation Guarantee; and (iii) tax-preferred voluntary superannuation contributions enhanced with other private savings. The Superannuation Guarantee requires employers to make superannuation contributions on behalf of almost all employees. ${ }^{2}$ The mandatory contribution rate gradually increased from 4 per cent in 1992 to 9 per cent by 2002 , and is legislated to reach 12 per cent by $2019 .^{3}$

The move to mass coverage under the Superannuation Guarantee coincided with (and was to some extent responsible for) a dramatic shift from DB to DC superannuation arrangements. Between 1982 and 2012, participation in 'pure' DB funds fell from 82 per cent to 2 per cent of superannuation fund members (Bateman \& Kingston, 2013). As a result, almost all Australian workers are compelled to participate in DC arrangements that require them to take responsibility for a series of

\footnotetext{
2 The few exclusions include workers under 18 or earning $<\$ 450$ per month, which is only around 7.5 per cent of average earnings.

${ }^{3}$ While the Superannuation Guarantee is specified in terms of DCs, DB plans can comply in some circumstances.
} 
actions relating to their retirement saving, including the choice of: (i) superannuation fund; (ii) voluntary contributions to supplement the mandatory Superannuation Guarantee (and whether to make these on a post- or pre-tax basis); (iii) allocating their contributions among increasingly longer menus of investment options; (iv) choosing the amount of life, total and permanent disability (TPD) and/or income insurance cover; and (v) deciding when to retire and what form of benefit to take at retirement.

The regulatory policy focus in the financial sector at the time of the introduction of the Superannuation Guarantee had increasingly emphasised market efficiency, with regulation limited to market conduct and information disclosure requirements (Gruen \& Wong, 2010). The underlying assumption was that ordinary people would be both engaged in financial matters and able to make appropriate decisions using the information provided under financial product disclosure requirements. ${ }^{4}$

Despite constant fiddling at the margin, the tax system continues to favour saving in superannuation over most other forms of household saving (Australia's Future Tax System (AFTS), 2010). Voluntary superannuation is encouraged through specific tax incentives and generally lower taxes on superannuation savings.

The design and specific application of the tax rules to superannuation contributions, fund investment income and benefits, however, is very complex, as illustrated in the Appendix. In brief, voluntary member contributions can be made on a pre- or post-personal income tax basis. Pre-tax contributions, also known as salary sacrifice contributions, are taxed at just 15 per cent, the same rate as employer contributions (subject to the so-called 'concessional contributions cap'). The tax benefit has varied over recent years with frequent changes to the superannuation tax rules and personal marginal income tax rates. For the 2012/13 financial year, voluntary pre-tax superannuation contributions were effectively tax-free for contributors earning up to $\$ 37,000$ (due to the Low Income Superannuation Contribution). Those earning above $\$ 37,000$ were provided with

\footnotetext{
4 Financial product disclosure requirements were incorporated into the Corporations Act in 2003 and were enhanced with the introduction of short form disclosure (comprising prescriptive simplified disclosure in a maximum of eight A4 pages) in 2012, although these are accompanied by fairly long pdf attachments.
}

tax benefits of between 19 and 31.5 percentage points compared with personal marginal income tax rates (subject to contribution caps). Furthermore, the government co-contribution scheme offered matching contributions of up to $\$ 500$ for low-income earners. In addition, superannuation fund investment income in the accumulation phase is also taxed at a maximum of 15 per cent (reduced further to the extent that the assets are invested in Australian equities) and are untaxed in the decumulation phase, while superannuation benefits taken after age 60 are tax-free.

Policy-makers assumed that members would use disclosed information when making their choice of superannuation fund, investment option and insurance cover, and would respond to the tax subsidies and incentives to supplement their mandatory superannuation with voluntary contributions. Aggregate data, however, reveal little take-up of choices or incentives. Exceptions are the increasing numbers of Australians who have chosen to set up a self-managed superannuation fund (SMSF), and in doing so have access to unlimited choice. While the SMSF sector accounts for around 3 per cent of total accounts, it is the fastest growing part of the industry and accounts for over one-third of total superannuation assets (APRA, 2013).

Returning to our discussion of the APRAregulated sector, despite being offered the choice of superannuation fund, anecdotal evidence indicates that less than 5 per cent of members of large superannuation funds actually choose their retirement fund: those who do not are placed in the default fund offered by their employer. Similarly, around two-thirds of industry fund assets and 43 per cent of superannuation assets (excluding SMSFs) are in default investment options (Australian Prudential Regulation Authority (APRA), 2013). Anecdotal evidence also suggests that this represents around 50-60 per cent of members. Even during the turbulent times of the GFC, few superannuation fund members varied their investment options (Gerrans, 2012). Moreover, only around one-third of members make voluntary superannuation contributions in excess of the mandatory contribution rate. Overall, this translates into 39 per cent of permanent workers making salary sacrifice and/or post-tax superannuation contributions and around 16 per cent of casual and short-term contract workers (Australian Bureau of Statistics (ABS), 2009). Finally, it appears that only around 20 per cent of those eligible take advantage of the government co- 
contribution (Australia's Future Tax System (AFTS), 2010).

Industry and regulators view the low take-up of incentives and concessions as evidence for a lack of interest or capability among ordinary fund members. But the evidence connecting attitudes directly to actions is scant. We aim to fill this gap using data on personal interest (as a proxy for engagement) and superannuation choices. To this effect, we next describe the specific institutional setting that generates the framework of our analysis.

\section{UniSuper Arrangements}

UniSuper is Australia's superannuation fund for higher education and research sector employees. It is one of the largest superannuation funds: at the end of June 2013 UniSuper had around 450,000 member accounts in DB and DC plans, and roughly $\$ 36.3$ billion in assets. ${ }^{5}$

Arrangements for members of UniSuper depend on employment status, earnings and the workplace agreement between the employees and employer. ${ }^{6}$ In particular, these arrangements differ between casual and short-term contract staff (subsequently called 'casual employees' or 'casuals') and staff on long-term contracts of at least two years (subsequently called 'permanent employees').

Casuals, including staff on contracts of less than two years, are enrolled in a DC plan under which the employers (i.e. the universities and research institutions) make the minimum contribution required under the Superannuation Guarantee, which is currently 9.25 per cent of earnings. They are also automatically covered for life and TPD insurance. However, once provided with default employer contributions and insurance cover, the casual employee members can take a number of specific actions. These include making additional ('voluntary') contributions from either pre- or post-tax earnings, changing their insurance cover, and changing their investment option(s). For low-income earners, voluntary contributions attract a government

\footnotetext{
5 Member and assets data from www.unisuper.com. au/about-us/about-unisuper. UniSuper is unusual in operating an open DB-type plan. Most Australian public and corporate DB plans closed to new members around $15-20$ years ago.

6 Industrial agreements mean that, unlike many workers in Australia, employees of universities may not elect to have their employer contribute to a pension plan other than UniSuper.
}

co-contribution up to $\$ 500$ p.a., but for high income earners, additional contributions could be vulnerable to the excess contributions tax. The insurance options include changing the level of cover for life and/or TPD insurance, adding cover for income insurance or opting out completely. In terms of investment choice, the casual employee members may select from a menu of 15 investment options varying by targeted returns, risk, asset allocation and management fees. Limited movement between investment options is allowed at zero fees. If new members do not select an investment option, their contributions go to the default investment option, i.e. a diversified 'balanced' fund that has a 70 per cent allocation to growth assets.

Permanent employees on long-term (i.e. two years or more) or continuing (tenured) contracts receive employer contributions to their superannuation account above the mandatory 9.25 per cent, typically amounting to 17 per cent of earnings. ${ }^{7}$ In addition, permanent employees contribute a further percentage of their wage, labelled 'standard member contribution' (which is a form of voluntary member contribution). The default rate of 'standard member contribution' is 7 per cent of post-tax earnings. On joining the university or at tenure, long-term employees are automatically enrolled in a DB plan and have 24 months from that date to elect to move to a DC plan. ${ }^{8}$ In addition, permanent employee members are automatically covered for a minimum level of death and disablement benefits. Apart from the higher contribution rates and some additional insurance coverage, long-term staff who elect to move from the DB plan hold a DC account similar to that described above for short-term staff (albeit at the higher rate of contributions).

Once provided with default employer contributions and insurance cover, and making themselves default standard contributions, the permanent employee members can take a number of specific actions. These include: (i) reducing the level of standard member contributions and/or changing these from post-tax to pre-tax contributions (and vice versa); (ii) making additional ('voluntary') contributions from either pre or post-tax earnings; (iii) changing their insurance cover; and (iv) making or changing their investment option(s)

\footnotetext{
7 A very small minority of employees receive a 14 per cent contribution.

${ }^{8}$ This has recently been extended by 12 months.
} 
from a menu of 15 investment options or opting for the default investment option.

Besides being able to take these plan-related actions as described above, UniSuper members can take actions to seek and access information about both superannuation in general and their own account. They can do the former by accessing the UniSuper website, taking an online tutorial, reading a product disclosure statement, or attending UniSuper seminars or webinars. As well, they can seek information about their own account by registering for and accessing Member Online, calling a UniSuper Call Centre, and seeking UniSuper financial advice (at a cost).

Our focus is precisely on the non-default behaviour, with respect to the specific actions we have just identified. Next we describe the samples analysed for non-default activity and engagement.

\section{Data}

We use two sets of data on UniSuper members. The first is a large, randomly selected sample from UniSuper members, which we label 'Full sample'. The second is a subsample of UniSuper members that participated in a marketing-oriented phone interview, which we label 'Marketing subsample'. We note that the UniSuper membership includes the broad range of occupations including academics as well as professional, administrative and technical staff on long-term, short-term and casual contracts.

Each month, UniSuper collects data on demographics, standard and voluntary contributions, superannuation plan type and investment option chosen, as well as some job (mobility) indicators for all members. We used the May 2012 wave of UniSuper data and restricted our sample to 'active members' defined by whether they or their employers had made any contributions to the fund over the previous four months. As a result, we ended up with a sample of 80,419 individuals, of whom 43.6 per cent had a permanent contract.

The 'Full sample' dataset includes several sources of information about the composition of the superannuation account balance, namely the total standard or voluntary contributions made in the past 12 months and whether these contributions were made pre- or post-income tax, as well as whether standard contributions were made at the (default) maximum level. Individuals who opted for the (default) 'balanced' investment allocation or purchased supplementary disability insurance are also identified. Other data include the number of employers currently contributing to the fund, the length of the contribution period (in years), the estimated annual wage and the type of employment contract, and age, gender and marital status. ${ }^{9}$

The 'Marketing subsample' dataset includes additional information about the attitudes of UniSuper members. Each month, UniSuper engages an independent marketing research company to interview 400 people selected from the UniSuper member database who have supplied a telephone number. This set of 400 respondents consists of 320 randomly selected members, 50 members who have telephoned the call centre in the last month and 30 pension members who have telephoned the call centre in the last month. Respondents to the telephone survey answer two questions on their attitudes. The first of these questions is a typical measure of 'advocacy' (Reichheld, 2003) and asks, 'Assuming there was nothing to stop you recommending UniSuper to a friend, family member or colleague, using a scale from 0 to 10 where 0 equals 'not at all likely', 5 is neutral and 10 equals 'extremely likely', how likely are you to recommend UniSuper?' The second question is meant to capture member 'involvement', defined as the 'perceived relevance of the object based on inherent needs, values and interests' (Zaichkowsky, 1985 p.342) and reads, 'Thinking about your superannuation in general, on a scale of 0 to 10 , where 0 is 'very disinterested' and 10 is 'very interested', how much interest do you personally take in your superannuation affairs?' The answers to these questions are recorded on an 11-point scale and then supplemented with selected information on these respondents from the existing UniSuper database. ${ }^{10}$

We use three months of Marketing survey data. After we excluded the 80 members each month who were selected because they contacted the call centre, and narrowed down to 'active' members who were non-pensioners, we end up with 675 respondents, of which 314 were permanent employees and 361 were casuals.

9 We use as proxy for marital status a variable denoting whether the individual had a spouse when he/ she became a UniSuper member.

${ }^{10}$ For the small Marketing subsample, we do not know marital status or whether standard or voluntary contributions were made pre- or post-income tax. Neither sample provides information about assets or debts outside UniSuper accounts. 


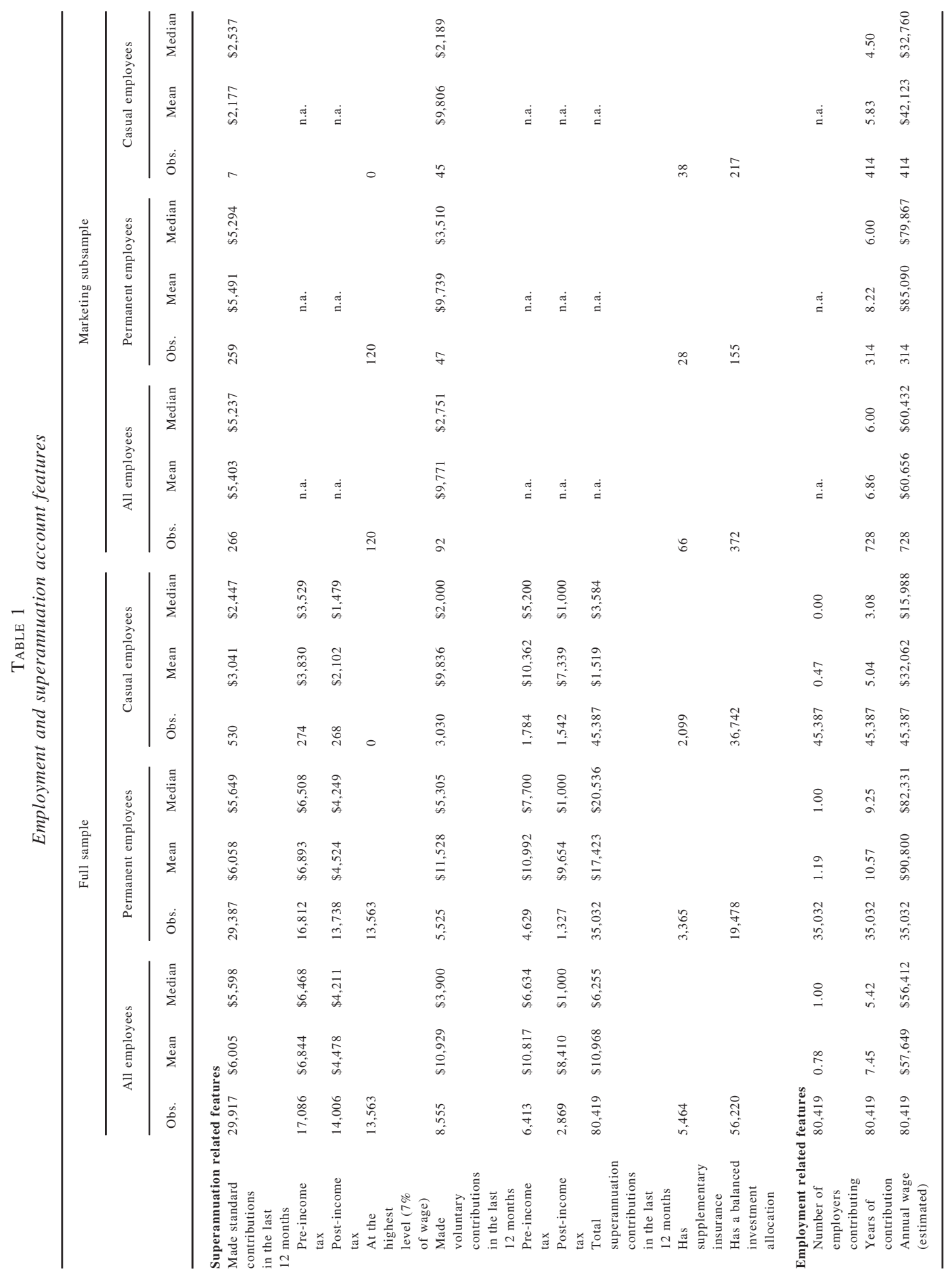




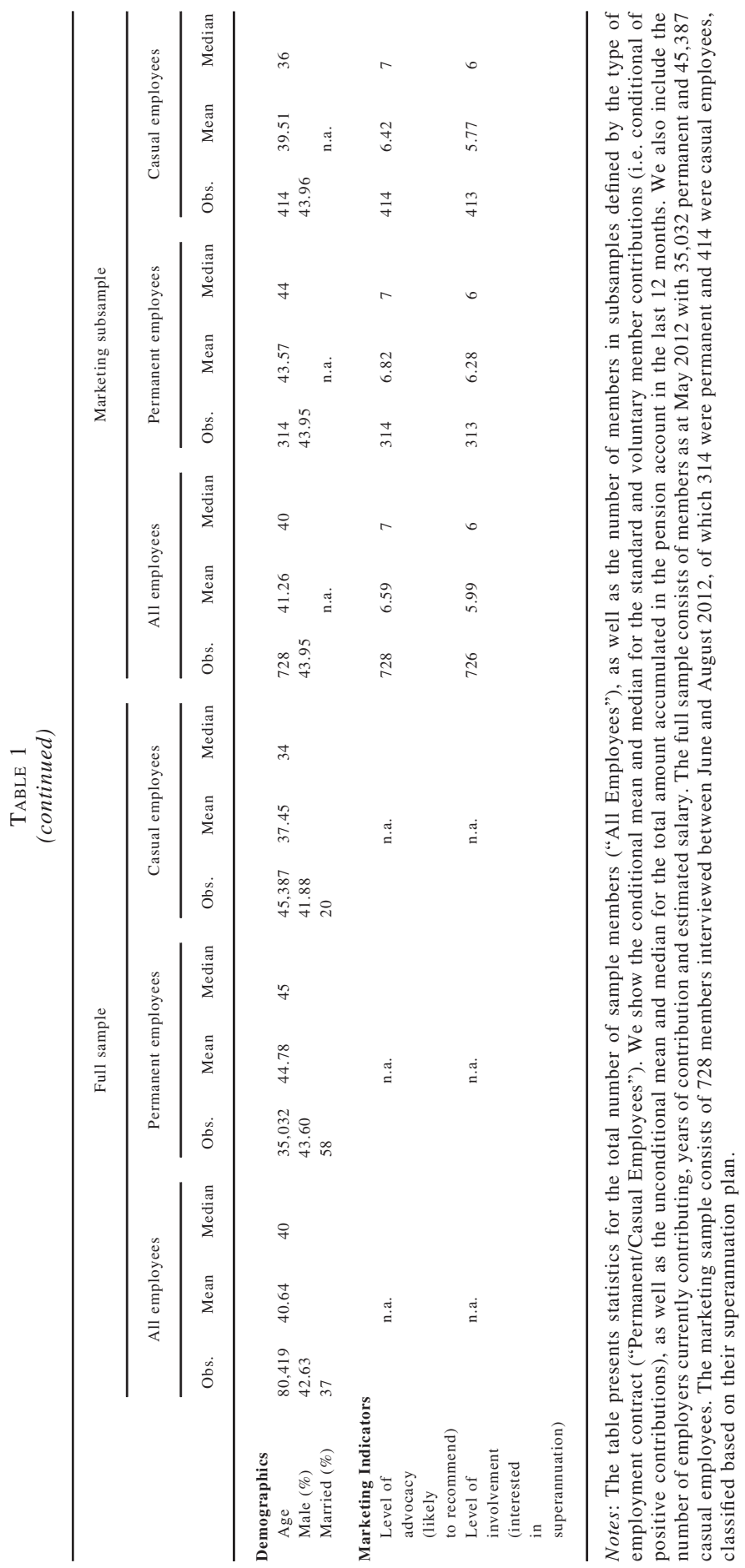


Table 1 presents descriptive statistics for the Full and Marketing databases, where comparable. Casual employees are slightly in the majority in both databases. The median age in the Full sample database is 40 years (permanent, 45 years; 34 years for the sample of casuals) and 40 years for the Marketing subsample (permanent, 44 years; 36 years for the sample of casuals). These figures are close to the median age of 42 years for the Higher Education sector from the Australian Bureau of Statistics (ABS) 2011 Census. The gender balances are also close to the Census records for this sector, which reports women at 58 per cent of employees. An important difference between the casual and permanent employees is marital status: permanents are three times more likely to be married than casuals. Other comparisons of permanent and casual employees between ABS and UniSuper data are difficult since the Census reports on full-time versus part-time employment status. According to the Census, full-time workers were 64 per cent of the Higher Education sector, suggesting that a large proportion of the sample reported here as 'casual' worked full-time hours, probably on contract.

Casual employees have much lower average wages, fewer years of contributions and lower contribution levels than permanent employees. This pattern is true for both databases, but the Full sample shows bigger differences between casual and permanent staff than the Marketing subsample. The Full database shows that voluntary contributions are made by 15.8 per cent of permanent employees and 6.7 per cent of casual staff, whereas the Marketing database has voluntary contribution rates at around 15 per cent and 10.9 per cent for permanent staff and casuals, respectively. Interestingly, the mean amount of voluntary contributions is similar for permanents and casuals, at around $\$ 10,000$, although the median is substantially lower for casuals, indicating a very long right tail. Membership of the default 'balanced' investment option in the Full (Marketing) sample is higher among casual employees at 80.9 per cent (52.4 per cent) compared with 55.6 per cent (49.4 per cent) for permanents. Overall, 30 per cent of accounts in the Full sample and 49 per cent of accounts in the Marketing subsample are not allocated to the default 'balanced' option. In addition, take-up of supplementary insurance in the Full sample is low for both permanents and casuals at 9.6 per cent and 4.6 per cent respectively.
A few anomalies in the data need comment. First, 530 casual employees in the Full sample and seven in the Marketing subsample are reported as having made a standard contribution in the past 12 months (which should only be relevant for permanent employees). Almost all of these were previously part of the DB component, but have shifted to the Accumulation 1 component when they took casual contracts. Second, the median number of employers contributing to casual employee accounts is zero in the Full sample. The reason is that many accounts are owned by casual workers whose contracts may have expired prior to May 2012, but who did receive or make contributions over the January-April period prior to that and so they are labelled 'active'.

\section{Discussion of Results}

The observed low levels of activity by members of superannuation funds led industry and government to infer that people are not involved with their retirement savings. Using the Marketing subsample, we aim to investigate who is making non-default decisions for their retirement savings and whether these are the same people who describe themselves as personally interested in superannuation (highly involved) and/or likely to recommend their fund (strong advocates).

\section{(i) Active Decisions and Subjective Interest/ Advocacy in the Marketing Subsample}

The Marketing database connects respondents' subjective ratings of their personal involvement and advocacy with a limited number of observable non-default activities, such as: (i) choosing a non-default investment option; (ii) purchasing supplementary insurance; (iii) registering with the online services to members; (iv) being active online over the past 12 months; (v) making any additional contributions over the past 12 months; (vi) not making the full standard member contribution; and (vii) making additional voluntary contributions over the past 12 months.

Table 2 presents preliminary correlation analysis of these decisions with demographic characteristics, likelihood of recommending UniSuper (advocacy) and subjective interest in superannuation (involvement). Significant coefficients $(<10$ per cent) are shaded grey. Involvement (personal interest) in superannuation is significantly, but weakly, positively correlated with active decisions (including online activity, 
TABLE 2

Correlations between respondent characteristics and actions (Marketing subsample)

\begin{tabular}{|c|c|c|c|c|c|c|c|c|c|}
\hline & $\begin{array}{c}\text { No } \\
\text { additional } \\
\text { contribution }\end{array}$ & Age & Male & $\begin{array}{l}\text { Log } \\
\text { annual } \\
\text { wage }\end{array}$ & $\begin{array}{c}\text { Years } \\
\text { of } \\
\text { contrib. }\end{array}$ & $\begin{array}{c}\text { Has } \\
\text { suppl. } \\
\text { insurance }\end{array}$ & $\begin{array}{l}\text { Investment } \\
\text { choice } \\
\text { other } \\
\text { than default }\end{array}$ & $\begin{array}{c}\text { Active } \\
\text { online } \\
\text { (last } \\
12 \text { mths) }\end{array}$ & Advocacy \\
\hline Age & -0.226 & & & & & & & & \\
\hline Male & 0.000 & 0.028 & & & & & & & \\
\hline $\begin{array}{l}\text { Log annual } \\
\text { wage }\end{array}$ & -0.333 & 0.159 & 0.168 & & & & & & \\
\hline $\begin{array}{l}\text { Years of } \\
\text { contribution }\end{array}$ & -0.207 & 0.372 & 0.038 & 0.224 & & & & & \\
\hline $\begin{array}{l}\text { Has } \\
\text { supplementary } \\
\text { insurance }\end{array}$ & -0.088 & 0.126 & -0.011 & 0.041 & 0.060 & & & & \\
\hline $\begin{array}{l}\text { Investment } \\
\text { choice }\end{array}$ & -0.083 & 0.047 & 0.118 & 0.178 & 0.036 & 0.053 & & & \\
\hline Active online & -0.114 & 0.134 & 0.126 & 0.105 & 0.112 & -0.025 & 0.137 & & \\
\hline Advocacy & -0.147 & 0.000 & -0.028 & -0.001 & 0.065 & 0.056 & 0.038 & 0.053 & \\
\hline Involvement & -0.161 & 0.295 & 0.112 & 0.132 & 0.143 & 0.11 & 0.138 & 0.208 & 0.173 \\
\hline
\end{tabular}

Notes: Table reports correlation between respondent characteristics, active choice and attitudes to superannuation. Correlations significant at the 10 per cent level or less are shaded grey. 'Supplementary insurance' indicates when the member has purchased additional insurance above the default level. 'Investment choice' indicates when a member has chosen an investment options for contributions that is not the default option. 'No additional contribution' indicates that the member has not made personal contributions above default levels in the past 12 months. 'Advocacy' is the respondent's score on an 11-point scale of likelihood of recommending UniSuper. 'Involvement' is the respondent's score on an 11-point scale of personal interest in superannuation. Coefficients significant at the 10 per cent level or less are shaded grey.

investment choice and additional contributions) and with advocacy. It is most strongly correlated with online activity. Older men with higher salaries are more likely to rate themselves as taking a high interest in their superannuation affairs, but not more likely to recommend UniSuper. Recommendations of UniSuper are positively correlated with making additional contributions, but not with other active choices. Personal interest in superannuation and support for a particular superannuation provider appear distinct attitudes, not related in the same way to non-default decisions.

Next we examine these relationships in more detail using multivariate models. We estimate the probability of members' non-default activities using a common set of control variables and responses to the advocacy and involvement scales. Our demographic covariates include member age in years, an indicator for gender (male $=1)$, the logarithm of the member's annual wage and the number of years that the member has been contributing to UniSuper. Reponses to the advocacy and involvement questions are grouped into three sets: $0-6,7-8$, and 9-10. This is in line with the approach suggested by Reichheld (2003) and followed by UniSuper, which implies grouping members into those who are seen as Detractors (0-6 ratings), Promoters ( 9 and 10 ratings), and Passives ( 7 and 8 ratings). This approach focuses on the 'intensely loyal', viz. the Promoters, who are prepared to recommend the fund. ${ }^{11}$ The asymmetry in these groupings also addresses the right-skew in responses. Table 3 reports marginal effects from logit model estimates of non-default decisions made by permanent and casual staff separately.

\footnotetext{
${ }^{11}$ While Reichheld's research among 4,000 customers established a link between individuals' actual referral and their purchase behaviour, he further maintained that the difference between Promoters and Detractors, known as the NetPromoter score is strongly correlated with a company's average growth rate. The net promoter approach has been widely adopted in industry, despite being questioned in academia (Keiningham et al., 2007).
} 


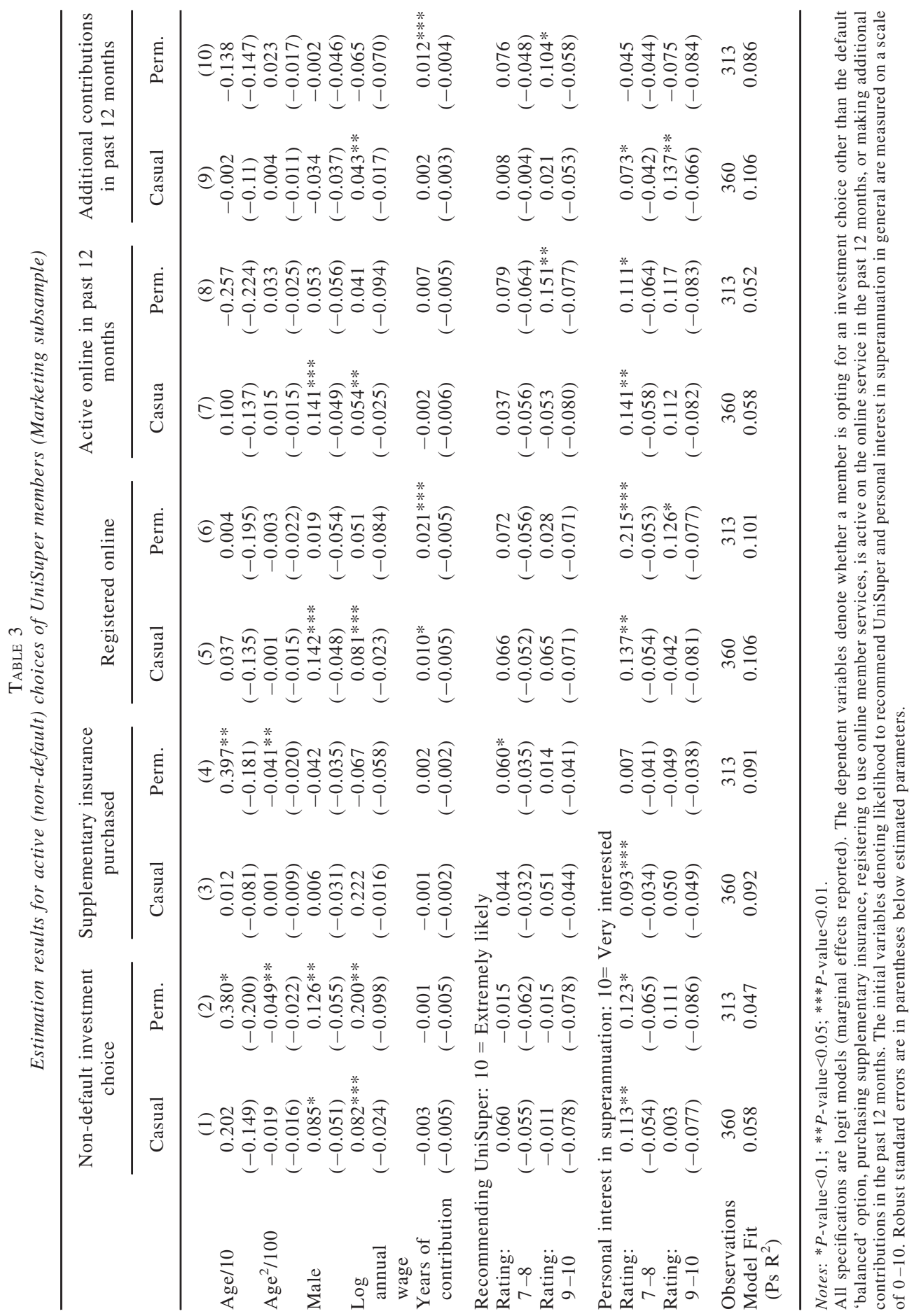


The relationships between demographics and active choices are unsurprising. Older permanent members are more likely to choose a non-default investment option or buy extra insurance, but in general, age is not significant when it comes to making additional contributions or engaging online. In contrast, members on higher salaries and males are more likely to select a non-default investment, while registering and accessing online services and making additional contributions seems to be affected by higher salaries only for casuals. ${ }^{12}$ Men on casual contracts are also more likely to register and use online services but otherwise gender is not significant.

Satisfaction with the specific superannuation fund looks to be critical to the decision to add contributions to the fund for permanent staff. Indeed, those who rate themselves as 'extremely likely' to recommend UniSuper (i.e. the 'Promoters') are significantly more likely to have made additional contributions over the past 12 months. Therefore, members who are strong advocates of UniSuper are most likely to supplement their savings using this vehicle. By contrast, casual employees are significantly more likely to have made additional contributions over the past 12 months if they rate themselves as personally 'very interested' in superannuation affairs. Unlike permanents, their likelihood of recommending the specific fund is not relevant. These employees may, therefore, think that superannuation is a good way to supplement their savings and this fund is a convenient location.

Satisfaction with UniSuper is also significantly higher among permanent staff who are active online. Interest in the fund itself fosters use of the website, most probably to monitor investment performance and track account balances.

A closer look at the intensity of personal interest reveals several interesting patterns. Members who rated their general interest in superannuation affairs slightly above the sample mean (i.e. the group who chose ratings of $7-8$ on the involvement scale) are typically more likely to take non-default actions, including investment choice, online registration, online activity and additional contributions. However, members who rate their personal interest even higher (at 9-10

\footnotetext{
12 This finding is also confirmed by the Full database estimates, both when considering the overall decision to voluntarily contribute and the decision to contribute at pre-tax rates.
}

on the involvement scale) are not. ${ }^{13}$ This seems to suggest that a moderate level of interest in superannuation is needed for most active decisions, but that intense interest or engagement does not make non-default activities more likely. To directly check this, we compared the marginal effects of the two ratings and find that only a few of these effects are monotonically increasing in subjective engagement measures. These are activity online over the past 12 months for permanent employees, and making additional contributions over the past 12 months for casual employees. Going from the lowest to the highest personal interest rating increases the probability of activity online by 13 percentage points $(0.44-0.57)$. Going from the lowest to the highest personal interest rating makes additional contributions by casuals 10 percentage points more likely $(0.07-$ $0.17)$. On the contrary, the probability of nondefault investment choice is higher for people of only moderate personal interest and actually declines for those who consider themselves 'very interested'. The marginal effect of interest on online registration for casuals peaks for the moderately interested, and is, in fact, lower for the most interested $(9-10)$ than for the least interested (0-6).

There are also two non-default activities that become probable as respondents rate themselves as more likely to recommend UniSuper. These are online activity and additional contributions, both for permanent employees. As the advocacy rating increases from the lowest to highest grouping, the probability of online activity increases by 16 percentage points $(0.43-0.59)$, while the probability of additional contributions increases by 10 percentage points $(0.80-0.90)$.

All in all, this analysis shows that the relationship between the subjectively assessed personal interest of superannuation fund members, and the non-default activities commonly used to measure that interest, is not straightforward. Members are more likely to make a non-default investment choice and/or register for online services if they have a moderate interest in superannuation, but becoming more interested in superannuation does not boost that likelihood. However, it is clear that the more personally interested and connected with the fund itself members become, the more likely they are to search out information, or monitor their account online activity. This result

\footnotetext{
13 The one exception is where online registration is more likely for 'very interested' permanent employees.
} 
TABLE 4

Estimation results for member contributions and total pension balance accumulated in the last 12 months Permanent Employees

\begin{tabular}{|c|c|c|c|c|c|c|c|}
\hline & \multicolumn{3}{|c|}{ Voluntarily contributing } & \multicolumn{3}{|c|}{ Standard contributing } & \multirow{2}{*}{$\begin{array}{c}\text { Log total } \\
\text { pension } \\
\text { wealth }\end{array}$} \\
\hline & $\begin{array}{c}\text { In } \\
\text { general }\end{array}$ & $\begin{array}{l}\text { At Pre-tax } \\
\text { rates }\end{array}$ & $\begin{array}{l}\text { Log Vol. } \\
\text { balance }\end{array}$ & $\begin{array}{l}\text { At Pre-tax } \\
\text { rates }\end{array}$ & $\begin{array}{l}\text { At Max. } \\
\text { rates }\end{array}$ & $\begin{array}{l}\text { Log Std. } \\
\text { balance }\end{array}$ & \\
\hline & (1) & (2) & (3) & (4) & (5) & (6) & (7) \\
\hline \multirow[t]{2}{*}{ Age/10 } & 0.003 & -0.043 & $0.873 * * *$ & $0.099 * * *$ & $0.308 * * *$ & $0.491 * * *$ & -0.021 \\
\hline & $(0.017)$ & $(0.038)$ & $(0.169)$ & $(0.024)$ & $(0.023)$ & $(0.034)$ & $(0.020)$ \\
\hline \multirow[t]{2}{*}{$\operatorname{Age}^{2} / 100$} & $0.010 * * *$ & $0.009 * *$ & -0.005 & $-0.005^{*}$ & $-0.024 * * *$ & $-0.044 * * *$ & $0.014 * * *$ \\
\hline & $(0.002)$ & $(0.004)$ & $(0.017)$ & $(0.002)$ & $(0.002)$ & $(0.003)$ & $(0.002)$ \\
\hline \multirow[t]{2}{*}{ Male } & $-0.035 * * *$ & $0.026 * * *$ & 0.007 & 0.003 & $0.082 * * *$ & $0.115 * * *$ & $0.084 * * *$ \\
\hline & $(0.003)$ & $(0.009)$ & $(0.039)$ & $(0.006)$ & $(0.005)$ & $(0.007)$ & $(0.005)$ \\
\hline \multirow{2}{*}{ Married } & $0.016 * * *$ & -0.006 & -0.021 & $0.054 * * *$ & -0.001 & $-0.025 * * *$ & $-0.028 * * *$ \\
\hline & $(0.003)$ & $(0.008)$ & $(0.039)$ & $(0.006)$ & $(0.006)$ & $(0.007)$ & $(0.005)$ \\
\hline \multirow{2}{*}{$\begin{array}{l}\text { Log } \\
\text { annual } \\
\text { wage }\end{array}$} & 0.002 & $0.243 * * *$ & $1.149 * * *$ & $0.160 * * *$ & $0.111 * * *$ & $1.105^{* * *}$ & $1.089 * * *$ \\
\hline & $(0.004)$ & $(0.014)$ & $(0.052)$ & $(0.010)$ & $(0.008)$ & $(0.010)$ & $(0.008)$ \\
\hline \multirow{4}{*}{$\begin{array}{l}\text { Years of } \\
\text { contribution } \\
\text { Employers }\end{array}$} & $0.002 * * *$ & -0.0007 & 0.004 & $0.003 * * *$ & $0.009 * * *$ & $0.012 * * *$ & $0.007 * * *$ \\
\hline & $(0.0002)$ & $(0.0006)$ & $(0.003)$ & $(0.0005)$ & $(0.0004)$ & $(0.0005)$ & $(0.0004)$ \\
\hline & $0.005 * * *$ & 0.006 & $-0.063 * * *$ & $0.053 * * *$ & $0.033 * * *$ & $0.026 * * *$ & $0.013 * * *$ \\
\hline & $(0.002)$ & $(0.005)$ & $(0.021)$ & $(0.004)$ & $(0.003)$ & $(0.004)$ & $(0.003)$ \\
\hline \multirow{3}{*}{$\begin{array}{l}\text { Observations } \\
\text { Model Fit }\end{array}$} & 35,032 & 5,525 & 5,525 & 29,387 & 35,032 & 29,387 & 35,032 \\
\hline & Ps $R^{2}$ : & PsR2: & $\mathrm{R}^{2}:$ & Ps R2: & PsR $^{2}$ : & R2: & $\mathrm{R}^{2}:$ \\
\hline & $16.50 \%$ & $13.13 \%$ & $34.23 \%$ & $4.22 \%$ & $8.44 \%$ & $41.39 \%$ & $52.32 \%$ \\
\hline
\end{tabular}

Notes: $* P$-value $<0.1 ; * * P$-value $<0.05 ; * * * P$-value 0.01 .

All specifications are logit models (marginal effects reported), except for specifications (3), (6) and (7) that are OLS models. The dependent variables denote whether a member is making voluntary contributions (in general and on a pre-tax basis), whether a member is making standard contributions (on a pre-tax basis or at the maximum level), the amount of voluntary and standard contributions, as well as the total pension amount accumulated in the past 12 months. Robust standard errors are in parentheses below estimated parameters.

supports the theory that defaults are partly a substitute for information acquisition and, hence may reduce externalities from personal search (Carlin et al., 2013).

Additional contributions by casuals become more likely as their personal interest in superannuation affairs rises, but a strong connection with UniSuper itself is needed to motivate additional superannuation contributions by permanent staff. This latter effect is probably influenced by the fact that most permanent staff may prefer to diversify retirement savings into other vehicles, because many will already have large balances with UniSuper.

\section{(ii) A Closer Look at Active Contribution}

Decisions Using the Full Sample

Next we examine in more depth the patterns of active decision-making regarding contribu- tions. To do so, we use the Full dataset to take a closer look at the relationship between demographics and employment features and the decision to make standard and voluntary contributions. However, because we do not know how members in the Full database rate their personal interest in superannuation or likelihood of recommending UniSuper, we cannot infer a direct connection between nondefault decisions and engagement. Tables 4 and 5 report estimates of a series of OLS and logit models, with the sample divided between permanent and casual employees.

The first section of Table 4 reports estimates related to the decision to make voluntary contributions for permanent staff. These contributions most likely generate tax advantages over other forms of retirement savings, even if they exceed the concessional contributions cap, and are made 
TABLE 5

Estimation results for member contributions and total pension balance accumulated in the last 12 monthsCasual Employees

\begin{tabular}{|c|c|c|c|c|c|c|}
\hline & \multicolumn{3}{|c|}{ Voluntarily contributing } & \multicolumn{2}{|c|}{ Standard contributing $^{\dagger}$} & \multirow{2}{*}{$\begin{array}{c}\text { Log total } \\
\text { pension } \\
\text { wealth }\end{array}$} \\
\hline & In general & $\begin{array}{l}\text { At Pre-tax } \\
\text { rates }\end{array}$ & $\begin{array}{l}\text { Log Vol. } \\
\text { balance }\end{array}$ & $\begin{array}{l}\text { At Pre-tax } \\
\text { rates }\end{array}$ & $\begin{array}{l}\text { Log Std. } \\
\text { balance }\end{array}$ & \\
\hline & (1) & (2) & (3) & (4) & (5) & (6) \\
\hline \multirow[t]{2}{*}{ Age/10 } & 0.003 & $0.277 * * *$ & $0.428 * * *$ & 0.214 & -0.056 & $-0.130 * * *$ \\
\hline & $(0.003)$ & $(0.065)$ & $(0.153)$ & $(0.148)$ & $(0.259)$ & $(0.009)$ \\
\hline \multirow[t]{2}{*}{$\operatorname{Age}^{2} / 100$} & $0.001 * * *$ & $-0.023 * * *$ & 0.005 & -0.014 & 0.028 & $0.021 * * *$ \\
\hline & $(0.0003)$ & $(0.007)$ & $(0.016)$ & $(0.016)$ & $(0.027)$ & $(0.001)$ \\
\hline \multirow[t]{2}{*}{ Male } & $-0.008 * * *$ & $0.144 * * *$ & $0.355 * * *$ & -0.059 & $0.324 * * *$ & 0.004 \\
\hline & $(0.001)$ & $(0.022)$ & $(0.054)$ & $(0.048)$ & $(0.099)$ & $(0.003)$ \\
\hline \multirow{2}{*}{ Married } & $0.016 * * *$ & -0.010 & $0.088 *$ & $0.088 * *$ & -0.100 & $0.046 * * *$ \\
\hline & $(0.001)$ & $(0.021)$ & $(0.053)$ & $(0.047)$ & $(0.092)$ & $(0.006)$ \\
\hline \multirow{2}{*}{$\begin{array}{l}\text { Log annual } \\
\text { wage }\end{array}$} & $0.013 * * *$ & $0.241 * * *$ & $0.393 * * *$ & $0.083 * * *$ & $0.686 * * *$ & $0.994 * * *$ \\
\hline & $(0.0006)$ & $(0.015)$ & $(0.027)$ & $(0.031)$ & $(0.108)$ & $(0.002)$ \\
\hline \multirow{2}{*}{$\begin{array}{l}\text { Years of } \\
\text { contribution }\end{array}$} & $0.001 * * *$ & $-0.004 * *$ & -0.002 & -0.001 & -0.003 & $0.003 * * *$ \\
\hline & $(0.0001)$ & $(0.002)$ & $(0.004)$ & $(0.004)$ & $(0.007)$ & $(0.0005)$ \\
\hline \multirow[t]{2}{*}{ Employers } & $0.007 * * *$ & 0.009 & $-0.036^{*}$ & 0.051 & 0.017 & $0.020 * * *$ \\
\hline & $(0.0007)$ & $(0.011)$ & $(0.028)$ & $(0.028)$ & $(0.049)$ & $(0.003)$ \\
\hline Observations & 45,387 & 3,030 & 3,030 & 530 & 530 & 45,387 \\
\hline \multirow[t]{2}{*}{ Model Fit } & Ps $R^{2}$ : & Ps R2: & $\mathrm{R}^{2}:$ & Ps R2: & R2: & $\mathrm{R}^{2}:$ \\
\hline & $20.42 \%$ & $19.98 \%$ & $27.44 \%$ & $6.60 \%$ & $35.65 \%$ & $96.26 \%$ \\
\hline
\end{tabular}

Notes: $* P$-value $<0.1 ; * * P$-value $<0.05 ; * * * P$-value $<0.01$.

All specifications are logit models (marginal effects reported), except for specifications (3), (6) and (6) that are OLS model. The dependent variables denote whether a member is making voluntary contributions (in general and on a pre-tax basis), whether is making maximum standard contributions, the amount of voluntary and standard contributions, as well as the total pension amount accumulated in the past 12 months. Robust standard errors are in parentheses below estimated parameters.

†Casual employees cannot make standard contributions. However, 530 individuals in our sample transited from a permanent contract (which allowed standard contributions) to a casual contract, and so, their account will still have a standard component for the transit year.

from post-tax income. $^{14}$ A quick glance at Table 4 reveals that demographic and employment-related features play more important roles than in the Marketing database analysis.

Results show the likelihood of voluntary contributions is 4 per cent higher for women than men, and increasingly likely for older employees. Women frequently experience disrupted work history, and, on average, have lower superannuation accumulations than men. It is, therefore, likely that they take advantage of lower family expenses in middle age to boost their retirement savings with additional contributions. The marginal effect of an additional year of age on the

14 However, the generous level of contributions already made by employers in this sector implies that many permanent staff making voluntary contributions are saving at rates exceeding 24 per cent of earnings. likelihood of voluntary contributions by permanent employees is 10 per cent at age 30 years, 17 per cent at age 40 and 27 per cent at age 50. ${ }^{15}$ Wage levels do not seem to matter overall, which is consistent with Marketing subsample estimates, although we do find a positive effect of higher wages on salary sacrifice contributions (see below).

Interestingly, some important features change when we consider those who contribute by salary sacrifice (or on a pre-tax basis), which could be seen as needing more effort to arrange than a post-tax contribution. First, we notice that men are 2.6 per cent more likely than women to voluntarily contribute on a pre-tax basis, and 8.2

15 Note that the estimates for the Marketing subsample in Table 3 had no significant age or gender effect. 
per cent more likely to contribute at maximum standard rates. Second, we note that these contributions are increasing in age, and strongly increasing in wages. For instance, the elasticity of voluntary contribution balances to wages (column 3 ) is $>1 .^{16}$

From the results reported in Table 5, voluntary contribution patterns among casual staff are also increasing in age and wages. Similar to permanent staff, we see men 14.4 per cent more likely to contribute via salary sacrifice, and women only 0.8 per cent more likely to contribute voluntarily overall. The wage elasticity of voluntary contributions is again positive, but this time considerably $<1$.

Failing to contribute at the maximum standard rate can mean that members of the DB division have their retirement benefit permanently reduced. Members who contribute the standard member contribution from their pre-tax salary are maximising their retirement payout, subject to staying within the concessional contribution cap. ${ }^{17}$ Those making non-default decisions by contributing at the maximum rate or contributing from pre-tax salary share similar characteristics: the probability of both is increasing with wages, period of contribution, number of employers contributing and strongly increasing in age.

Overall, the estimates of demographic and employment-related effects on contribution choices from the Full database confirm the estimated relationships from the Marketing database. Here we show that the advantages offered by augmenting employer contributions with salary-sacrificed, maximum-level member contributions are taken up by older, longer-tenured, higher-income employees. Fewer than half of the permanent staff in our survey paid the full standard contribution, and around half used salary sacrifice. Even fewer made voluntary contributions, although the pattern of take-up was similar across both permanent and casual employees. Interestingly, our results suggest that the same types of individuals in Australia, and around the same proportion (only 15 per cent of permanent employees here), make use of the 'active' incen-

\footnotetext{
16 The Marketing database does not separate salary sacrifice contributions and so, we cannot compare these results.

${ }^{17}$ Some members on high salaries already receiving a 17 per cent contribution from their employer may be better off making the member contribution post-income tax.
}

tives as were found by Chetty et al. (2012) in their study of savings decisions in Denmark.

\section{$V$ Conclusions}

Recent retirement incomes policy has favoured 'libertarian paternalism' where individuals are defaulted or 'nudged' into choice patterns designed to compensate for a lack of capability or interest. Since the introduction of the Superannuation Guarantee in 1992, the Australian retirement savings paradigm has followed this direction. In place of rational, well-informed and capable members, the policy is now built to accommodate 'disengagement'. The critical evidence for disengagement among superannuation fund members is an observed low level of nondefault decision-making. However, many members may be 'choosing' default settings, and the connection between subjective interest (involvement) and non-default decisions has not been rigorously tested.

Using a unique new dataset of UniSuper fund members, we examine the relationship between two key measures of subjective interest (or engagement) in superannuation and a series of non-default decisions. Respondents in the dataset rate their personal interest in superannuation affairs and their likelihood of recommending UniSuper to friends or family on an 11-point scale. Along with demographics and employment data, we use these subjective involvement and advocacy scales to explain the investment and insurance choices, registration and activity on member websites and additional contribution patterns.

This analysis shows that the relationship between members' subjective evaluation of their own engagement and the non-default activities (that are commonly used to measure that engagement) is not straightforward. Investment choice and/or registering for online services is associated with moderate, but not high, personal involvement (or interest) and is unrelated to advocacy. However, the more personally interested and connected members become, the more likely they are to search out information, or monitor their online account activity. In fact, increasing personal interest can increase the probability of these activities by more than 10 percentage points. Similarly, additional contributions by casuals become more likely as their personal interest in superannuation affairs rises, but connection with UniSuper itself is needed to motivate additional contributions by permanent staff. 
The quote from the Super System Review (2010) at the beginning of this article argued that the superannuation system should work for people who are financially illiterate and uninterested in their mandatory savings. That there is low financial literacy among a large proportion of superannuation fund members is indisputable (Bateman et al., 2012; Agnew et al., 2013). And results here suggest that very uninterested members are indeed less likely to take non-default choices. Our results, however, also prove that more engagement does not produce more activity in any simplistic sense. For example, assuming that a majority of members are uninterested (or disengaged) because they contribute into the default investment option is a mistake, according to our findings. We also establish that it is crucial to distinguish between members by employment status, age and income when evaluating engagement using active choice patterns. In other words, policy prescriptions should not be based on simplistic interpretations of member engagement.

In future research, we plan to study the connection between personal interest, defaults and information acquisition (Carlin et al., 2013). Highly interested superannuation members are active online, possibly monitoring their accounts and comparing different strategies. An index of information acquisition and monitoring behaviour is likely to be a better pointer to engagement than non-default choices.

\section{REFERENCES}

Agnew, J., Bateman, H. and Thorp, S.J. (2013), 'Financial Literacy and Retirement Planning in Australia', Numeracy, 6(2), 1-25.

Antolin, P., Payet, S. and Yermo, J. (2012), 'Coverage of Private Pension Systems: Evidence and Policy Options', OECD Working Paper on Finance, Insurance and Private Pensions, No. 20, OECD Publishing.

Australian Bureau of Statistics (ABS) (2009), Employment Arrangements, Retirement and Superannuation Australia, Cat. No. 6361.0, Canberra.

Australian Government (2010), Stronger Super, 16 December 2010. Canberra.

Australian Prudential Regulation Authority (APRA) (2013), Statistics: Annual Superannuation Bulletin (issued 9 January 2013).

Australia's Future Tax System (AFTS) (2010), Report to the Treasurer, December 2009, Part Two, Detailed Analysis, Part 1 of 2, Canberra.

Bateman, H. and Kingston, G. (2013), 'Restoring a Level Playing Field for Defined Benefits Superannuation', paper presented at the 18th Melbourne Money and Finance Conference, 1-2 July 2013.
Bateman, H. and Piggott, J. (1997), Private Pensions in OECD Countries - Australia, Occasional Papers No.23, Labour Market and Social Policy, OECD, Paris.

Bateman, H., Kingston, G. and Piggott, J. (2001), Forced Saving: Mandating Private Retirement Incomes, Cambridge University Press, Cambridge, UK.

Bateman, H., Eckert, C., Geweke, J., Louviere, J.J., Thorp, S.J. and Satchell, S. (2012), 'Financial Competence and Expectations Formation: Evidence from Australia', Economic Record, 88, 39-63.

Benartzi, S. (2012), Save More Tomorrow: Practical Behavioral Finance Solutions to Improve 401(k) Plans. Portfolio/Penguin, USA.

Benartzi, S. and Thaler, R.H. (2013), 'Behavioral Economics and the Retirement Savings Crisis', Science, 339 (8 March), 1152-3.

Beshears, J., Choi, J.J., Laibson, D. and Madrian, B.C. (2009), 'The Importance of Default Options in Retirement Saving Outcomes: Evidence from the United States', in Brown, J., Liebman, J. and Wise, D.A. (eds), Social Security policy in a Changing Environment. University of Chicago Press, Chicago, IL; 167195.

Brown, K., Gallery, G., Gallery, N. and Guest, R. (2004), 'Employees' Choice of Superannuation Plan: Effects of Risk Transfer Costs', Journal of Industrial Relations, 46, 1-20.

Carlin, I.B., Gervais, S. and Manso, G. (2013), 'Libertarian Paternalism Information Production and Financial Decision Making', Review of Financial Studies, 26(9), 2204-28.

Chetty, R., Friedman, J.N., Leth-Petersen, S., Nielsen, T.N. and Olsen, T. (2012), 'Active vs. Passive Decisions and Crowdout in Retirement Savings Accounts: Evidence from Denmark', NBER Working Paper No. 18565.

Diamond, P. (1977), 'A Framework for Social Security Analysis', Journal of Public Economics, 8(3), 27598.

Diamond, P. (2011), 'Economic Theory and Tax and Pension Policies', Economic Record, 87, 2-22.

Fry, T., Heaney, R. and McKeown, W. (2007), 'Will Investors Change Their Superannuation Fund Given Choice?', Accounting and Finance, 47(2), 267-83.

Gerrans, P. (2012), 'Retirement Savings Investment Choices in Response to the Global Financial Crisis: Australian Evidence', Australian Journal of Management, 37(3), 415-39.

Gerrans, P. and Clark-Murphy, M. (2004), 'Gender Differences in Retirement Savings Decisions', Journal of Pension Economics and Finance, 2(2), 145-64.

Gerrans, P., Clark-Murphy, M. and Speelman, C. (2010), 'Asset Allocation and Age Effects in Retirement Savings Choices', Accounting and Finance, 50, 301-19.

Gruen, D. and Wong, T. (2010), 'MySuper-Thinking Seriously About the Default Option', Economic RoundUp, 2010 (4), 33-42. 
de Haan, T. and Linde, H.J. (2012), Good Nudge Lullaby. 10 December 2013 Available from http:// www.wiwi.uni-jena.de/eic/files/deHaan\&Linde_Goo dNudgeLullaby_\%202013.pdf

Hedesström, T.M., Svedsäter, H. and Gärling, T. (2007), 'Determinants of the Use of Heuristic Choice Rules in the Swedish Premium Pension Scheme: An Internet-Based Survey', Journal of Economic Psychology, 28(1), 113-26.

Keiningham, T.L., Cooil, B., Andreassen, T.W. and Aksoy, L. (2007), 'A Longitudinal Examination of Net Promoter and Firm Revenue Growth', Journal of Marketing, 71(3), 39-51.

Madrian, B. and Shea, D. (2001), 'The Power of Suggestion: Inertia in 401(k) Participation and Sav- ings Behavior', Quarterly Journal of Economics, 116, 1149-87.

Mitchell, O.S. and Utkus, S. (2006), 'How Can Behavioral Finance Inform Retirement Plan Design', Journal of Applied Corporate Finance, 18(1), 82-94.

Reichheld, F.F. (2003), 'The One Number You Need to Grow', Harvard Business Review, 81(12), 46-55.

Super System Review (2010), Super System Review Final Report, 30 June 2010. Canberra.

Thaler, R.H. and Sunstein, C.R. (2003), 'Libertarian Paternalism', American Economic Review, 93(2), 175-9.

Zaichkowsky, J.L. (1985), 'Measuring the Involvement Construct', Journal of Consumer Research, 12, 34152. 


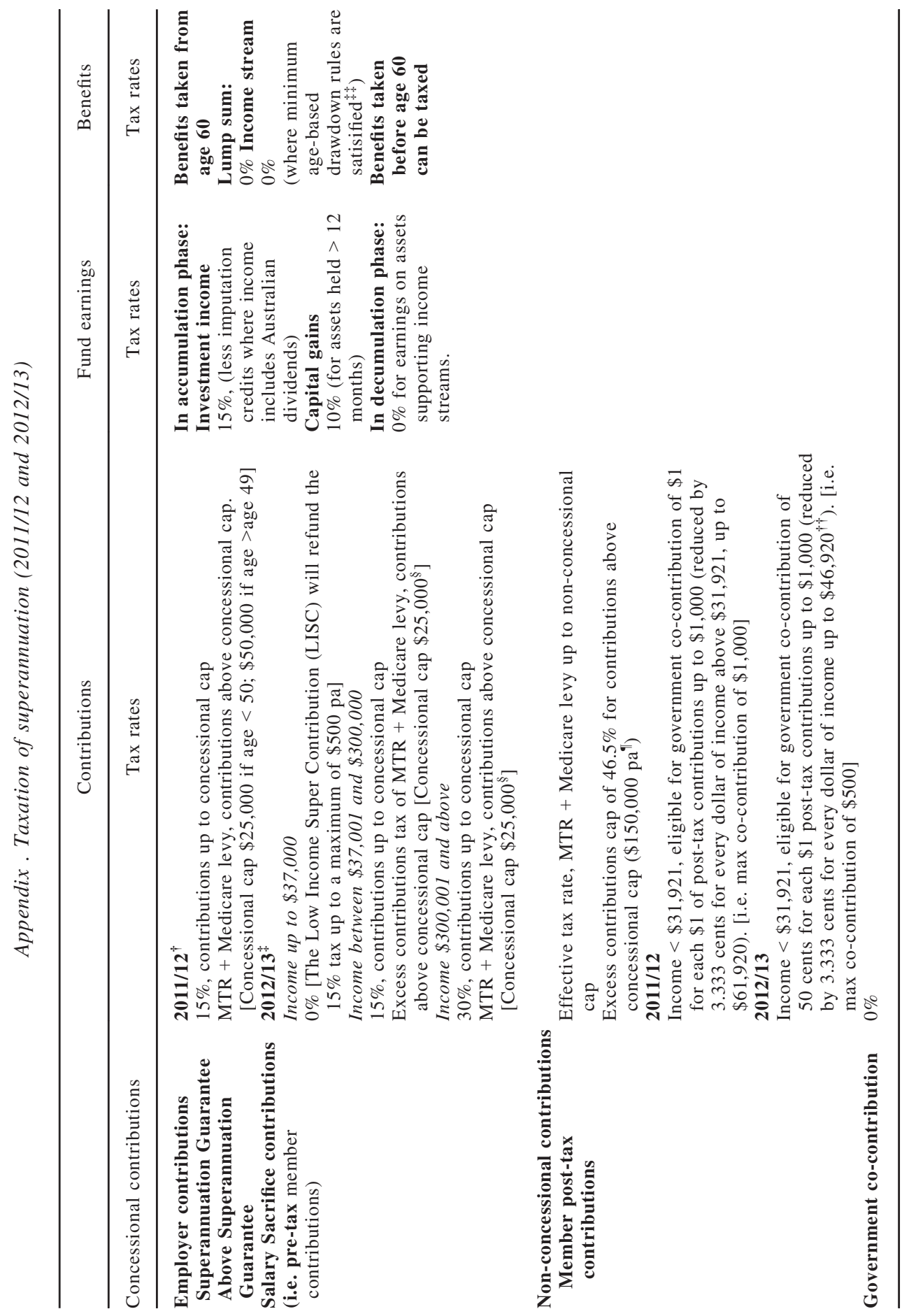



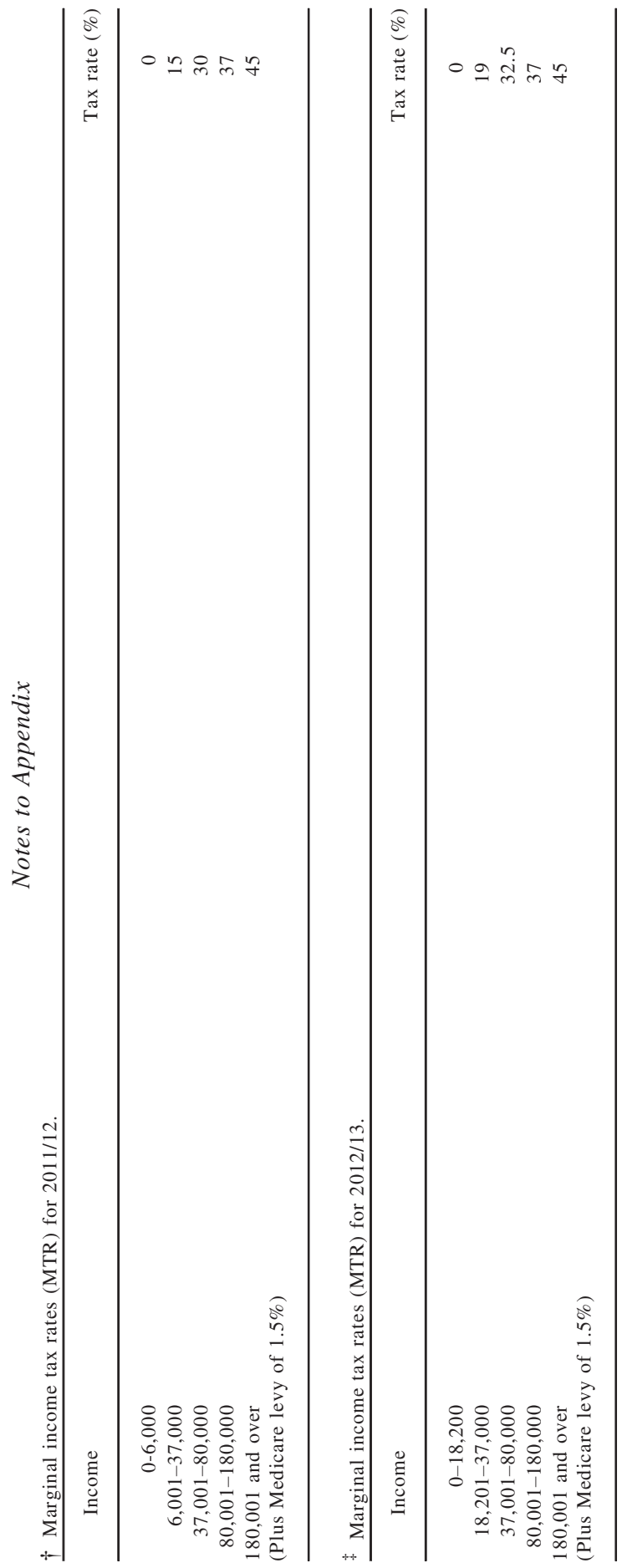

0
$n$
$n$
$\infty$
0
0
.0
0
0
$\vdots$
0
0
0
0
0
0
0
0
0
0

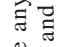

ㄹำ

苛

๑ 音吉

म

品

$\because$ 范

in o

a

ㄷㅇㅇ

$\because \quad \frac{0}{n}+$

उलें

ㄴ.

王递

तี

हैं के क्ष

范

击实 in

भिं

范苛苛

$\exists$ 正

$8 . \Xi$ 菏

임

n.

点 20

.

三 금

3. ख

원을 증

证。

路哭营

品

s) 킁

政

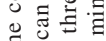

话里

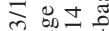

穴过

छ

它打 